Jurnal Biota Vol. 7 No. 1, 2021

36 | ISSN: 2460-7746 (online); ISSN: 2528-262X (print)

\title{
Macroinvertebrates Diversity in Sundak Beach, Gunung Kidul, Yogyakarta
}

\author{
Yunita Fera Rahmawati \\ Biology Program, Faculty of Mathematics and Natural Sciences, Yogyakarta State University, \\ Indonesia
}

email: yunita.fr@uny.ac.id

Article Info

Keyword:

Diversity

Macroinvertebrates

Sundak Beach

Quadratic transect

\section{Article history:}

Received: $21 / 11 / 2020$

Revised: 23/12/2020

Accepted: $24 / 12 / 2020$

\begin{abstract}
Macroinvertebrate diversity is one of the biologicals and ecological indicators that allow it to become a reference in determining water quality. This study aimed to inventory and study the diversity of macroinvertebrate species using the $1 \times 1 \mathrm{~m}^{2}$ transect method along the Sundak Beach, Gunung Kidul, Yogyakarta. The research was conducted on Sunday, October 13 ${ }^{\text {th }}$, 2019, with a quadratic transect method of 10 stations from the lowest low tide to the middle of the sea. The data obtained in this study was the result of macroinvertebrates species inventory in each sampling point and the number of individuals of each species. The data was then analyzed using the Shannon-Weiner diversity index $\left(H^{\prime}\right)$. The results showed 45 macroinvertebrate species with 2590 numbers of individuals were found on the Sundak Beach. The most common species were Gastropods with 16 species, while the most individual species were Ophiuroidea (730 species). The diversity index of 1.28351 indicates that the diversity of macroinvertebrates in Sundak Beach is categorized as medium diversity.
\end{abstract}

Copyright (C) 2020 The Author(s). All Right Reserved

\section{Introduction}

As the largest archipelago country in the world, Indonesia has a coastline length of $95.181 \mathrm{~km}$. Beaches in Indonesia offer a variety of beauty and abundant biota. Karst beaches in Gunung Kidul have similarities regarding geological conditions and the process of forming beach morphology (Ramadani et al., 2019). One of the beaches is Sundak Beach. Sundak Beach is one of many beaches in the southern part of Java Island. This beach is located in Sidoharjo, Gunung kidul, Yogyakarta Special Region Province. Sundak Beach is situated between two rock cliffs on the left and right. In the middle of the beach, the substrate is white sand with relatively coarse size with a little rocky shape, while near the cliffs, the substrate is coral. Characteristics Sundak Beach is known for its rocky shores and big waves so that no boats can be seen passing by (Nurmiyati, 2013).

Sundak Beach has an undulating topography with steep slopes. On the east side of this beach, a cave is formed from a rock, which is $\pm 12 \mathrm{~km}$. Another uniqueness of this beach is that apart from the existence of coral cliffs, there are also 
underground river channels that have freshwater flow and there is a basin between the stretch of the beach. The marine life that can be found on this beach is very diverse, including Gastropods, Crustaceans, Echinoidea, Malacostraca, Ophiuroidea, Bivalvia, Polychaeta, Anthozoa, Anopla and Polyplacophora. In one part of the coast, there is a low density of seagrass and algae growth (Nugroho et al., 2014).

Common macroinvertebrates are very sensitive to changes in the environment they occupy so that they can be used as biological and ecological indicators of a species of an aquatic ecosystem (Tjokrokusumo, 2011). The number of species, the number of individuals, and diversity in the macroinvertebrates community can be used as references in determining water quality.

Species diversity in a community is defined as a group of organisms that establish a community (Campbell et al., 2008). Furthermore, Brower et al., (1998), specified that species diversity is a manifestation of community structure. A community is stated to have high species diversity if the number of each species is the same as a whole.

The species diversity index is used to determine the diversity of species in waters. Species diversity is a characteristic at a community level based on its biological organization. Species diversity can be used to express community structure and measure community stability, namely the ability of a particular community to maintain its environment to remain stable despite disturbance to its components (Rusdi et al, 2020).

Research to take inventory and find the diversity of macroinvertebrate species at Sundak Beach Gunung Kidul, Yogyakarta.

\section{Materials and Methods}

This research was conducted on Sunday, October $13^{\text {th }}, 2019$ at Sundak Beach, Yogyakarta. Macroinvertebrates sampling was taken at 10 stations using the "quadratic transect" method using a 1x1 m cylindrical pipe frame (Loya, 1978). Transects are drawn perpendicularly from the lowest tide point to the middle of the sea and observations are made every 10 meters (10 plots total) along the line transect. Placement of quadratic every $10 \mathrm{~m}$ along the transect is considered to be representative of the locations where macroinvertebrate samples are present. In each plot, all macroinvertebrates were observed, recorded, photographed, and counted on the number of individuals of each species in the quadratic transect.

Data obtained to determine the diversity of species. The diversity of macroinvertebrate species found is interpreted in the diversity index calculated using the Shannon Wienner index calculation (Brower et al., 1998).

Note :

$$
\mathrm{H}^{\prime}=-\Sigma \mathrm{Pi} \ln \mathrm{Pi}
$$

$\mathrm{H}^{\prime}$ : Diversity index

$\mathrm{Pi}$ : Proportion of species-I ( $\mathrm{ni} / \mathrm{N}$ )

ni: Number of individuals of type I

$\mathrm{N}$ : Total number of individuals of all

types

Diversity index analysis follows Fatiqin (2019), namely: $\mathrm{H}^{\prime}>3$ indicates high diversity, $1 \leq \mathrm{H}^{\prime} \leq 3$ indicates medium diversity, and $\mathrm{H}^{\prime}<1$ indicates low diversity.

Diversity is determined by the number of species and evenness of the abundance of each individual species obtained. The greater the value of a diversity, the more species obtained and this value is highly dependent on the total value of the individual of each species. The diversity $\left(\mathrm{H}^{\prime}\right)$ has the greatest value if all individuals come from different genus or species, while the 
smallest ones come from a genus or species only (Odum, 1994).

\section{Results and Discussion \\ Inventory of Macroinvertebrates at Sundak Beach}

The results of the macroinvertebrates inventory at Sundak Beach found 45 macroinvertebrate species. The total number of individuals found was 2590 individuals. Among the 45 species found, the five species with the highest numbers were Ophiomastix annulosa (730), Ophiomastix elegans (488), Ophiomastix vaiabilis (361), Echinometra mathaei (111), and Echinometra calamaris (79). The identification of Ophiuroidea species was carried out with the help of the literature of Clark and Rowe (1971) and Arnold and Birtles (1989).

Studies on the diversity of Echinoderms on Sundak beach have been conducted by Yusron (2015), Firmandana et al., (2014), and Nugroho et al., (2014). Most of the Ophiuroidea groups are found in certain places or have zoning. If grouped according to classes, the number of macroinvertebrate species in Sundak Beach is presented in Table 1 .

Table 1. Group of Macroinvertebrates in Sundak Beach

\begin{tabular}{ccc}
\hline Class & $\boldsymbol{\Sigma}$ species & $\boldsymbol{\Sigma}$ individuals \\
\hline Ophiuroidea & 3 & 1579 \\
Gastropoda & 16 & 344 \\
Echinoidea & 4 & 292 \\
Malacostraca & 4 & 153 \\
Crustacea & 9 & 149 \\
Bivalvia & 2 & 34 \\
Polychaeta & 2 & 17 \\
Anthozoa & 2 & 17 \\
Anopla & 2 & 3 \\
Polyplacophora & 1 & 2 \\
\hline
\end{tabular}

Based on Table 1, it is known that if seen from the number of species, the most species from the Gastropod class were found, namely 16 species, whereas when viewed from the number of individuals, the species from the
Ophiuroidea class had the most number of individuals, namely 1579 individuals.

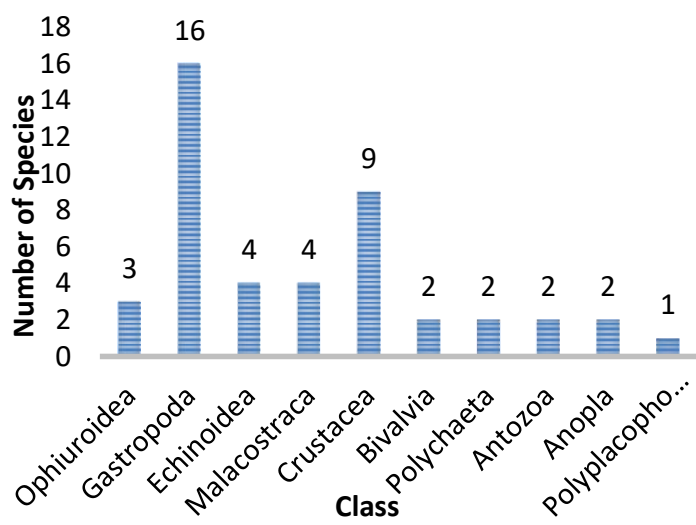

Figure 1. Composition of a Number of Species Based on The Class of Macroinvertebrates in Sundak Beach

The results of the macroinvertebrates inventory at Sundak Beach showed there were 10 classes identified. According to Basuki (2015), macroinvertebrates found in waters have properties such as very sensitive to water quality changes, relatively many species with different responses and limited movement, making it easier to observe and identify.

Observations show some several species or classes are abundant compared to other species or classes. If the number of individuals is observed, the most species are Ophiuroidea, while the most species found are from the Gastropods classes. This is related to the conditions and characteristics of the habitat around Sundak Beach. Sundak Beach, a type of sandy beach, allows many species in the Gastropods to occupy it. Gastropods are one of the key groups in the food web. Besides that, the reproduction of Gastropods is also influenced by environmental factors such as light, turbidity, temperature, salinity, and $\mathrm{pH}$. According to the statement Odum (1994), stated that an ecosystem's physical, chemical, and the biological environment will affect its biota. 


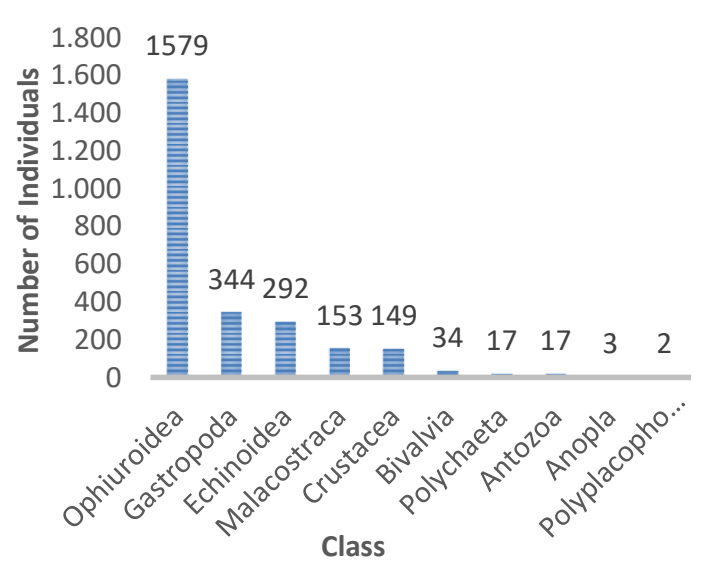

Figure 2. Composition of a Number of Individuals Based on The Class of Macroinvertebrates in Sundak Beach

Table 1 shows two groups of aquatic worms found on the Sundak Beach, namely Anopla and Polychaeta. At the lowest tide point, Sundak Beach is an area with a sand substrate making it suitable as a habitat for aquatic worms (Saputra et al., 2015). This is stated in the research of Siahaan, et al., (2012), that marine worms are often found in sandy or muddy habitats in both fresh and seawater.

\section{Diversity of Macroinvertebrate Species in Sundak Beach}

From the analysis, the $\mathrm{H}^{\prime}$ result is 1.28351, which indicates that the diversity of levels of the Sundak Beach macroinvertebrates is medium. This condition is caused by several factors, including species composition, number of individuals for each type, and substrate characteristics between stations. The lack of a diversity of substrates on the Sundak Beach causes the macroinvertebrates' diversity index to be classified as medium. The diversity of seagrass and seaweed is influenced by various topographic zones of the coast, such as sand zones, growth zones of seagrass and seaweed, coral reef zones and tubir zones (Yudasmara, 2013). Besides, the high and low diversity index can also be caused by various factors, including the number of individuals found, the dominance of certain species, and the substrate's homogeneity.

Diversity index $\left(\mathrm{H}^{\prime}\right)$ can be interpreted as a systematic description of a community structure and can facilitate analyzing information about the type and number of organisms. Magurran (1988) stated the diversity index value $\left(\mathrm{H}^{\prime}\right)$ is related to species richness at a particular location but is also influenced by the abundance distribution of each species. The higher the diversity of value, the higher the ecosystem's productivity, the pressure on the ecosystem and the stability of the ecosystem. This is confirmed by Krebs (1989) that the more and evenly the number of individual members in an ecosystem, the greater the diversity index $\left(\mathrm{H}^{\prime}\right)$ will be.

If the analysis of each macroinvertebrates class is found in Sundak Beach, the analysis of the diversity index for each class can be presented in Table 2.

\section{Table 2. Results of Diversity Index Calculations for Each Class of Macroinvertebrates in Sundak Beach}

\begin{tabular}{cccc}
\hline Class & $\boldsymbol{\Sigma} \mathbf{~ S p}$ & $\mathbf{H}^{\prime}$ & $\boldsymbol{\Sigma}$ in \\
\hline Ophiuroidea & 3 & 0.30169 & 1579 \\
Gastropoda & 16 & 0.26813 & 344 \\
Echinoidea & 4 & 0.24607 & 292 \\
Malacostraca & 4 & 0.16711 & 153 \\
Crustacea & 9 & 0.16427 & 149 \\
Bivalvia & 2 & 0.05688 & 34 \\
Polychaeta & 2 & 0.03299 & 17 \\
Anthozoa & 2 & 0.03299 & 17 \\
Anopla & 2 & 0.00783 & 3 \\
Polyplacophora & 1 & 0.00553 & 2 \\
\hline \multicolumn{4}{l}{ Note: Sp (Spesies); in (individuals) }
\end{tabular}

The results of the analysis in Table 2 show that the class with the highest diversity index value $\left(\mathrm{H}^{\prime}\right)$ is Ophiuroidea, since its very high number of Ophiuroidea individuals, namely 1579 individuals. The high dominance of a species will affect the diversity of other species in the research location (Supratman et al., 2018). The high 
dominance of a species can be caused by several factors, such as the contaminated habitat condition with the amount of garbage observed around the coast and exploitation by the surrounding community. So the species that can live in this habitat are only species that are tolerant of pollution. Besides, the availability of abundant food sources is only for certain species, so that other species cannot compete. The diversity of marine life is strongly influenced by the condition and quality of the coral reef ecosystem on the coast (Alexander, 2011).

\section{Conclusion}

The results showed that at Sundak Beach, Yogyakarta there were found 45 macroinvertebrate species which were grouped into 10 classes. The number of individuals macroinvertebrates animals found was 1579 individuals. The highest number of individuals found was Ophiomastix annulosa with 730 individuals. The analysis of the diversity index showed that the Shannon-Wienner index of macroinvertebrates at Sundak Beach was 1.28351. These results indicate that macroinvertebrate diversity is in the medium category.

\section{Acknowledgment}

I thank Drs. Triatmanto, M.Si. who help and kindly share some references related to macroinvertebrates. We are very grateful to anonymous reviewers for comments on our preliminary draft to make this paper improve.

\section{References}

Alexander, H. 2011. Kelimpahan dan Keragaman Megabentos di Perairan Teluk Ambon. Jurnal Oseanologi dan Limnologi. 37(2): 277-294.

Arrnold, P,W., Birtles, R, A. (1989). SoftSediment Marine Invertebrates of Southeart Asia and Australia: A Guide to Identification.
Townsville: Australian Institute of Marine Science, pp.272.

Basuki, T.M. (2015) Penyederhanaan Parameter Kualitas Air Untuk Monitoring Dan Evaluasi Kinerja Daerah Aliran Sungai. Indonesian Forest Rehabilitation Journal. 3 (1), 13-21

Brower, J.J., Jerold, Z., \& Von Ende, C. (1990). Field and Laboratory Methods for General Ecology $\left(3^{\text {rd }}\right.$ $E d)$ USA: W.M.C. Brown Publishing.

Campbell, N.A., Reece, J.B., Urry, L.A., Cain, M.L., Wasserman, S.A., Minorsky, P.V., Jackson, R.B. 2008. Biologi. Jakarta: Erlangga.

Clark, A.M. \& F.W.F. Rowe. 1971. Monograph of Shallow Water Indowest Pasific Echinoderms. London: Trustess of the British useum (Natural History).

Fatiqin, A. 2019. Plankton Biodiversity in The Burai River of Ogan Ilir District, Sumatera Selatan. Biota: Biologi dan Pendidikan Biologi, 12(1), 14-21.

Firmandana, T.C., Suryanti., Ruswahyuni. 2014. Kelimpahan Bulu Babi (Sea urchin) Pada Ekosistem Karang dan Lamun Di Perairan Pantai Sundak, Yogyakarta. Management of Aquatic Resources Journal (MAQUARES), 3(4), 41-50.

Krebs, C.J. 1989. Ecology Fourth Edition. The University of British Columbia. Vancouver.

Loya, Y. 1978. Plotless and Transect Methods, In: D.R. Stoddard., and R.E. Johannes (ed.) Coral Reef Research Methods, (UNESCO).

Magurran AE. 1988. Ecological diversity and its measurement. Princeton University Press, New Jersey.

Nugroho, W., Ruswahyuni., Suryanti. 2014. Kelimpahan Bintang Mengular (Ophiuroidea) Di Perairan Pantai Sundak Dan Pantai 
Kukup Kabupaten Gunungkidul, Yogyakarta. Management of Aquatic Resources Journal (MAQUARES). 3(4), 51-57.

Nurmiyati. (2013). Keragaman, Distribusi Dan Nilai Penting Makro Alga Di Pantai Sepanjang Gunung Kidul. Bioedukasi: Jurnal Pendidikan Biologi. 6 (1), 12-21.

Odum Ep. 1994. Dasar-Dasar Ekologi. Yogyakarta: Gadjah Mada University Press.

Ramadani, A., Tamam, M., Santoso, H., \& Al Yamini, T. H. (2020). Diversity of Edible Flora and Biotourism Potential Development of Botany Adventure in Turgo, Mount Merapi National Park Yogyakarta. Jurnal Biota, 6(2), 7177.

Rusdi, R., Setyobudiandi, i., \& Damar, A., 2020. Study Of Potential And Sustainable Management Of Mangrove Ecosystem In Pannikiang Island, Barru Regency, South Sulawesi. Jurnal Ilmu dan Teknologi Kelautan Tropis. 12 (1), 119-133.

Saputra, A., Marjono., Sari, D. P., \& Suwarno. 2015. Keanekaragaman Makro-invertebrata di Pantai Sepanjang, Gunung kidul, Yogyakarta. Seminar Nasional Konservasi dan Pemanfaatan Sumber Daya Alam. 1 (1), 1-10.
Siahaan, R., Andry, I., Dedi, S., \& Lilik, B.P. 2012. Keanekaragaman Makrozoobentos sebagai Indikator Kualitas Air Sungai Cisadane, Jawa Barat-Banten. Jurnal Bioslogos, 2(1), 1- 9 .

Supratman, O., Farhaby, A. M., \& Ferizal, J. 2018. Kelimpahan dan Keanekaragaman Gastropoda Pada Zona Intertidal di Pulau Bangka Bagian Timur. Jurnal Enggano, 3 (1), 10-21.

Tjokrokusumo. S.W. 2011. Bentik Makroinvertebrata Sebagai

Bioindikator Polusi Lahan Perairan. Jurnal Hidrosfir, 1(1), 820.

Yudasmara, G. A. (2013). Keanekaragaman Dan Dominansi Komunitas Bulu Babi (Echinoidea) Di Perairan Pulau Menjangan Kawasan Taman Nasional Bali Barat. Jurnal Sains Dan Teknologi, 2(2), 213-220.

Yusron, E. 2015. Keanekaragaman Jenis Phiuroidea (Bintang Mengular) di Perairan Pesisir Gunungkidul, Yogyakarta. Makara Sains. 14 (1), 75-78. 